A N NALES

UNIVERSITATIS MARIAE CURIE-SKŁODOWSKA LUBLIN - POLONIA

VOL. XXX, 3

SECTIO J

2017

Uniwersytet Jana Kochanowskiego w Kielcach. Wydział Pedagogiczny i Artystyczny

\title{
LIDIA PAWELEC
}

lidia.pawelec@ujk.edu.pl

\section{Kursy, szkolenia i warsztaty dla nauczyciela- wymóg czasów współczesnych}

Courses, Training and Workshops for a Teacher. The Requirement of Modern Times

\section{STRESZCZENIE}

Współczesny nauczyciel musi sprostać wielu nowym zadaniom dydaktycznym, wychowawczym, opiekuńczym i organizacyjnym. Aby mógł zrealizować nowe cele, musi posiadać inne kompetencje niż dotychczas. Współczesna rzeczywistość edukacyjna potrzebuje nauczycieli otwartych i twórczych, pełniących rolę przewodników i tłumaczy. Kompetencje w tym zakresie nauczyciel zdobywa nie tylko podczas studiów, ale również w okresie swojej pracy, korzystając z bogatej oferty kursów, warsztatów i szkoleń. Idealny nauczyciel powinien posiadać nie tylko kompetencje merytoryczne, psychologiczno-pedagogiczne, komunikacyjne, negocjacyjne i autoedukacyjne, ale i osobowość twórczą, kreatywną i innowacyjną. W związku z potrzebą kształcenia kreatywności i twórczej postawy nauczycieli na rynku istnieje bogata oferta różnorodnych kursów, szkoleń i studiów podyplomowych proponujących zajęcia, które zajmują się właśnie tą sferą.

Słowa kluczowe: kreatywność; innowacyjność; twórczość

\section{WPROWADZENIE}

Różnorodne przeobrażenia społeczne, gospodarczo-ekonomiczne, polityczne i ustrojowe, które dokonały się w Polsce po 1989 r., stały się źródłem istotnych zmian dotyczących funkcjonowania systemów opiekuńczo-wychowawczych i kulturalno-oświatowych. Uwidoczniły się one m.in. w postaci systematycznie rosnącej liczby funkcji i zadań stawianych placówkom oświatowym przez społeczeństwo. W związku z tym praca wykonywana przez nauczyciela zaczęła wiązać się z coraz to większymi wymaganiami i oczekiwaniami. Społeczeń- 
stwo uważa, że nauczyciel powinien efektywnie rozwiązywać wiele problemów dydaktycznych, wychowawczych, opiekuńczych, profilaktycznych, kulturalnych i społecznych (Kowalczuk-Walędziak 2012, s. 10). Konieczność sprostania tym oczekiwaniom skłania nauczycieli do stosowania w swojej pracy innowacyjnych rozwiązań, szukania możliwości nowatorskiego działania i takich sposobów aktywizowania uczniów, które pobudzą ich do samodzielnego myślenia i kreatywnego działania (Dudel 2014, s. 7). Chcąc podejmować działania nieszablonowe i niekonwencjonalne oraz stosować metody twórcze pedagogicznie, współczesny nauczyciel stoi przed koniecznością stałego poszerzania swoich kompetencji.

\section{TWÓRCZOŚĆ, INNOWACYJNOŚĆ, KREATYWNOŚĆ - DEFINICJE POJĘĆ}

Tworzenie to jedna $\mathrm{z}$ cech, które wyróżniają człowieka. Jest on swoistego rodzaju homo creatorem, który zmienia i ulepsza siebie oraz swoje otoczenie, a przynajmniej posiada predyspozycje, by to robić. Twórcze działania należy rozumieć jako „wykraczające poza prostą percepcję” (Tatarkiewicz 1976, s. 302), które mają postać materialną (konkretny wytwór, rzecz) lub ideową (wyobrażenie, myśl). Są one wytworem, procesem, zespołem specyficznych cech osobowości (zdolności, uzdolnień) lub zespołem stymulatorów społecznych (Strzałecki 1969, s. 13-27). Twórczość można rozumieć jako ,aktywność przynoszącą wytwory nowe i społecznie użyteczne" (Pietrasiński 1969, s. 9) - wówczas nacisk położony jest przede wszystkim na szczególną rolę wytworu, efektu aktywności. Tak rozumiana twórczość będzie dotyczyła m.in. twórczości poetyckiej, malarskiej itd. Z punktu widzenia pracy nauczyciela chodzi raczej o twórczość jako cechę osobowości. W tym przypadku trzeba rozumieć to pojęcie jako:

(...) zdolność do pewnego rodzaju kompozycji, wytworów, pomysłów, które są (...) nowe lub nowatorskie i nie były znane osobie wytwarzającej. (...) to aktywność wyobraźni lub myślowa synteza, których produkt nie jest tylko podsumowaniem. Może ona obejmować tworzenie nowych modeli i łączenie informacji pochodzących z poprzednich doświadczeń oraz przeniesienie dawnych relacji do nowych sytuacji i wprowadzenie do nich pewnych zmiennych. (...) celowa lub ukierunkowana na cel, a nie może być to jałowe fantazjowanie - chociaż nie musi mieć bezpośredniego zastosowania albo też być doskonałym i dokończonym wytworem. Może także przybierać formę wytworu artystycznego, literackiego lub naukowego, albo mieć charakter proceduralny lub metodologiczny (Hurlock 1985, s. 74-75).

Badania twórczości jako cechy człowieka wyodrębniają dwa podejścia: 1) elitarne, którego zwolennicy uważają, że twórczość odnosi się tylko do osób wybitnych, i 2) egalitarne, którego zwolennicy twierdzą, że każdy człowiek jest twórczy (Dyrda 2004, s. 12).

Proces twórczy oznacza niezwykle skomplikowane działanie poddane wpływowi różnorodnych czynników. Podczas niego w umyśle człowieka zachodzą na- 
stępujące operacje: rozumowanie dedukcyjne (dowodzenie, że jedno twierdzenie wypływa z poprzednich), rozumowanie indukcyjne (wyciąganie wniosków z niekompletnego zbioru danych), metaforyzowanie (odnoszenie się do jednej rzeczy w terminach właściwych dla innej), skojarzenia, abstrahowanie, transformacja (zmiany w cechach obiektu, by jego końcowa postać była inna od wyjściowej) (Nęcka 1995, s. 71-86). Najważniejszą cechą postawy twórczej jest aktywne i otwarte ustosunkowanie się do otaczającej rzeczywistości oraz podejmowanie przez nią i rozwiązywanie problemów o różnorodnym charakterze (Karwowski 2008, s. 6).

Z pojęciem twórczości nierozerwalnie łączy się innowacyjność. Słowo to pochodzi z języka łacińskiego, gdzie innovatio oznacza odnowienie i dotyczy przejawów nowoczesnej pracy człowieka, której efektem jest określony wytwór, czyli innowacja, będący przedmiotem, ideą lub wzorem zachowania (Gaza 1998, s. 26). Innowacja oznacza pojawienie się nowej rzeczy, metody działania, stworzenie nowych możliwości, zdobycie nowych źródeł informacji i zmiany w organizacji (Drabik-Podgórna 2005, s. 28). Może być również rozumiana jako proces, który obejmuje działania związane z kreowaniem i wdrażaniem jakiegoś pomysłu lub jako zdolność do poszukiwania, wdrażania i upowszechniania innowacyjnych pomysłów (Wojtczuk-Turek 2009, s. 92).

Innowacja pedagogiczna definiowana jest natomiast jako ,zmiana struktury systemu szkolnego (dydaktycznego, wychowawczego) jako całości lub struktury ważnych jego składników - w celu wprowadzenia ulepszeń o charakterze wymiernym" (Okoń 2001, s. 138). Dzięki takim zmianom system jest ulepszany, co oznacza lepszą pracę nauczycieli i uczniów, lepsze treści programowe i lepsze warunki materialno-społeczne pracy szkolnej. Innowacje pedagogiczne należy rozumieć jako wyspecjalizowaną formę działalności i produkty, które składają się na ogół z doświadczeń innowacyjnych współczesnej rzeczywistości. Oznaczają one zmiany o charakterze rozwojowym, prowadzące do wzbogacenia kultury wychowania o nowe wartości. Dzięki nim możliwe jest przejście od stanu dobrego do lepszego, niosą postęp i są nowymi składnikami doświadczenia pedagogicznego (Schulz 1996, s. 59). Innowacja z pewnością oznacza jakąś zmianę, jednak trzeba mieć świadomość tego, że każda innowacja jest zmianą, natomiast nie każda zmiana jest innowacją. Rys. 1 przedstawia rodzaje innowacji pedagogicznych.

W obrębie wymienionych na rys. 1 typów innowacji wyróżnia się: innowacje dydaktyczne (metodyczne, programowe i organizacyjne zmiany dotyczące sposobów nauczania), innowacje wychowawcze (zmiany w zakresie celów, metod, treści, zasad i osiągnięć związanych z pedagogicznymi oddziaływaniami wychowawczymi), innowacje opiekuńcze (zmiany w zakresie celów, metod, treści i zasad w obszarze funkcji opiekuńczych), innowacje terapeutyczno-zdrowotne (zmiany w zakresie kształcenia, wychowania i opieki, dotyczące problematyki kondycji zdrowotnej jednostki i społeczeństwa), innowacje przedmiotowe (dzia- 


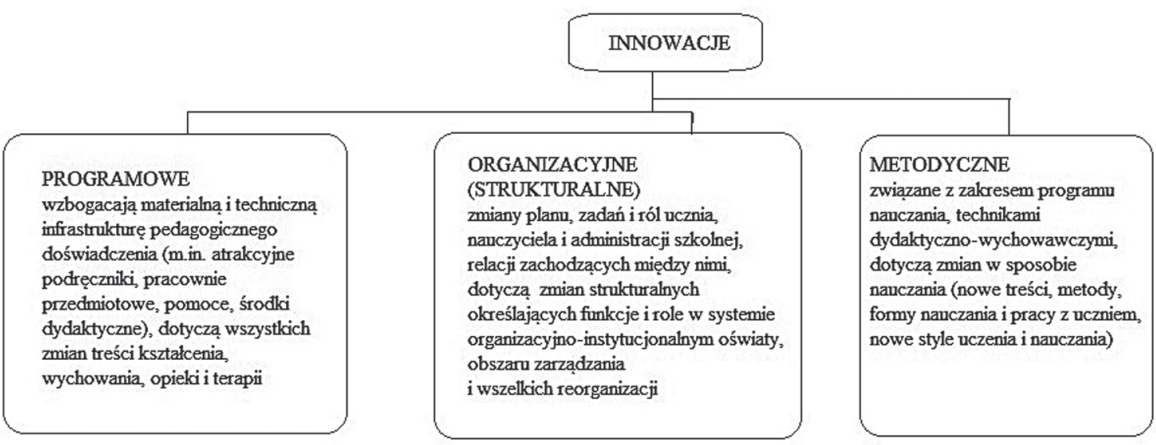

Rys. 1. Typy innowacji w pedagogice

Źródło: (Karwat 1987, s. 11-18; Okoń 1979, s. 330-336; Kotarba-Kańczugowska 2009, s. 20; Informacje o trybie i warunkach uzyskania pozytywnej opinii na prowadzenie innowacji... 2011).

łania zmieniające charakter dotychczasowego programu nauczania przedmiotu przez nowe cele edukacyjne, treści i wymagane osiągnięcia), eksperyment pedagogiczny (modyfikacja warunków organizowania zajęć edukacyjnych, zakresu treści nauczania), reforma oświatowa (systemowa zmiana formalno-prawna i organizacyjna, dotycząca działań pedagogicznych w obszarze edukacji narodowej) (Such 2007).

Warunkiem wprowadzania innowacji jest zawsze krytyczna ocena istniejącego stanu w danym obszarze działania. Nauczyciel widzi potrzebę wprowadzenia zmian i chce ich dokonać, aby sytuacja była lepsza. Podejmując pracę nad wprowadzeniem innowacji, nauczyciel kieruje się przede wszystkim chęcią uatrakcyjnienia zajęć edukacyjnych, podniesienia efektów własnej pracy i osobistej satysfakcji.

Nie sposób być innowacyjnym i twórczym bez odpowiednich kompetencji w zakresie kreatywności. Cecha kreatywności zawsze odnosi się do osoby charakteryzującej się postawą twórczą i wiąże się z procesem tworzenia. Jest nierozerwalnie złączona z motywacją, dotyczy więc osób, które chcą się rozwijać przede wszystkim w procesie urzeczywistniania się twórczości codziennej, rozumianej jako możliwość i działania konieczne do rozwiązywania problemów codzienności. Kreatywność można zatem uznać za element samoświadomości jednostki, który powinien być urzeczywistniany w procesie kształcenia i wychowania. Nauczyciel ma bowiem wspomagać uczniów w kreatywnym podejściu do życia, które charakteryzuje się wzmożoną wewnętrzną aktywnością (Cudowska 2004, s. 13-14).

Cecha kreatywności odnosi się do potencjału jednostki i jest cechą ciągłą, co oznacza, że nie ma ludzi „niekreatywnych”, lecz są kreatywni w mniejszym lub 
większym stopniu. Wyznacza ona potencjał do twórczego funkcjonowania. Należy dostrzegać różnice między twórczością a kreatywnością - twórczość to proces, natomiast kreatywność to zdolność. Nauczyciel kreatywny będzie skuteczny w twórczym myśleniu i innowacyjny w działaniu. Kreatywność zawsze wiąże się z wymyślaniem czegoś nowego i lepszego od tego, co istnieje (Szmidt 2008, s. 5). Przejawia się w konkretnej postaci obserwowalnego zachowania, które polega na produkcji nowych i wartościowych wytworów; wytworem może być także samo zachowanie (Nęcka 2001, s. 6). Cecha kreatywności odnosi się do osobowości człowieka, co oznacza, że może być ćwiczona i rozwijana za pomocą odpowiednich czynności. Bez wątpienia zdolność ta pomaga w życiu zawodowym, ale również w funkcjonowaniu na gruncie osobistym. Człowiek kreatywny szybciej i łatwiej znajduje sposoby rozwiązania różnorodnych problemów, a jego życie jest dużo bogatsze w doświadczenia i przeżycia. Dlatego warto uczestniczyć w różnego rodzaju treningach kreatywności (Nöllke 2007, s. 10).

\section{POTRZEBA KREATYWNOŚCI W EDUKACJI}

Idealny nauczyciel powinien posiadać nie tylko kompetencje merytoryczne, psychologiczno-pedagogiczne, komunikacyjne, negocjacyjne i autoedukacyjne, ale również osobowość twórczą, kreatywną i innowacyjną. Stracił bowiem monopol na przekazywanie wiedzy na rzecz pełnienia roli przewodnika po skomplikowanej rzeczywistości współczesnego świata. Jest inspiratorem, naukowym i duchowym opiekunem ucznia, który ma przygotować go do samodzielnego uczenia się, kształtowania umiejętności pozyskiwania informacji z różnych źródeł, ich selekcjonowania i wartościowania oraz budowania nowych wartości na bazie otrzymanych informacji. Nauczyciel-kreator korzysta z edukacji refleksyjnej polegającej na zerwaniu z ilością informacji na rzecz ich jakości i odbudowuje dialog z uczniem (Morbitzer 2003, s. 263-265). To on kreuje postawy twórcze uczniów, odkrywa ich potencjał i inspiruje ich rozwój osobisty na każdym szczeblu edukacji. Trzeba przy tym podkreślić, że nie dotyczy to jedynie przedmiotów artystycznych, ponieważ nauczyciel twórczy pomaga także w rozwoju emocjonalnym i intelektualnym uczniów, w odnalezieniu przez nich indywidualności, tworzeniu poczucia własnej wartości i osiąganiu sukcesów (Jezierska 2012, s. 30).

Nie jest łatwo być nauczycielem-kreatorem, gdyż wymaga to posiadania określonych cech związanych z funkcjonowaniem intelektualnym, emocjonalnym i organizacyjnym. Sprzyja temu z pewnością autentyczne współbycie z uczniami, które opiera się na empatii i zainteresowaniu ich sprawami i problemami oraz na życzliwości, tolerancji. To porozumienie i współbycie z wychowankami kształtuje się spontanicznie albo jest budowane w konkretnych sytuacjach (Dymara 2003, s. 257-259). 
Nauczyciel twórczy jest zarazem nauczycielem i artystą, który powołuje nowe osobowości do istnienia; jest ponadto wynalazcą, gdyż odkrywa nowe środki dydaktyczne, ale też twórcą i użytkownikiem wiedzy, wykorzystującym zdobytą wiedzę do tworzenia nowej. Nauczyciel twórczy jest dodatkowo innowatorem, który projektuje i wprowadza nowe rozwiązania i pomysły, staje się podmiotem, tworzywem i produktem twórczych działań (Piątek, Wańczyk, Pokorska 2007, s. 146).

W obecnej rzeczywistości edukacyjnej wymaga się, by twórczość była stylem pracy każdego nauczyciela. Twórczy nauczyciel oznacza osobę pomysłową, otwartą na pomysły innych, ciągle wzbogacającą wiedzę merytoryczną i podnoszącą kwalifikacje zawodowe. Nie pracuje on w sposób schematyczny i sformalizowany, ponieważ wciąż poszukuje, sprawdza i pracuje nad nowymi rozwiązaniami w swojej działalności. Można określić go jako nowatora doskonalącego stale swoje umiejętności. Jako takiego cechuje go postawa poszukiwacza i badacza sprawdzającego różne sposoby rozwiązań danego zadania. Taki nauczyciel nie ogranicza swojej działalności do podręcznika i ćwiczeniówki (Borawska 1988, s. 30). Twórcza praca sprzyja rozwojowi aktywności uczniów oraz podnosi poczucie własnej wartości nauczyciela, zaspokaja jego potrzebę uznania i sukcesu.

\section{KURSY I SZKOLENIA DLA NAUCZYCIELI - BADANIA WŁASNE}

\section{Podstawy metodologiczne}

W związku z potrzebą kształcenia kreatywności i twórczej postawy nauczycieli na rynku istnieje bogata oferta różnorodnych kursów, szkoleń i studiów podyplomowych proponujących zajęcia, które zajmują się tą właśnie sferą. Podjęte badania miały na celu ukazanie różnorodności tych ofert, ich form, czasu trwania. Sformułowano następujące problemy badawcze:

1. Jakie rodzaje kursów, szkoleń i warsztatów kształcących postawę twórczą i kreatywność ma do dyspozycji współczesny nauczyciel?

2. Jakie cele realizują kursy, szkolenia i warsztaty kształcące postawę twórczą i kreatywność dla nauczycieli?

3. Jakie treści i zagadnienia poruszane są podczas trwania kursów, szkoleń i warsztatów kształcących postawę twórczą i kreatywność współczesnych nauczycieli?

W badaniach zastosowano metodę analizy dokumentów, przy czym jako dokument potraktowano zasoby internetowe, które w dużym stopniu odzwierciedlają rzeczywisty obraz zagadnienia. Obecnie bowiem każda instytucja czy uczelnia, organizująca tego typu szkolenia, zamieszcza ofertę na swojej stronie internetowej lub wśród ogłoszeń. Świadomie pominięto nazwy placówek i organizacji, które te kursy proponują. 


\section{Wyniki badań}

W efekcie analizy zasobów internetowych odnaleziono szereg propozycji kursów i warsztatów skierowanych do nauczycieli, które mają rozwijać ich kreatywność i pomagać kształtować indywidualność twórczą uczniów. Wybrane propozycje zostały przedstawione $\mathrm{w}$ tab. 1 .

Tab. 1. Przykładowe kursy i szkolenia dotyczące kształcenia postawy twórczej i kreatywności nauczycieli

\begin{tabular}{|c|c|c|c|}
\hline Forma & Cele & Program & $\begin{array}{l}\text { Czas } \\
\text { trwania }\end{array}$ \\
\hline \multicolumn{4}{|c|}{ Kreatywny nauczyciel } \\
\hline $\begin{array}{l}\text { Zajęcia teoretyczne, } \\
\text { trening twórczości }\end{array}$ & $\begin{array}{l}\text { Określenie i ćwiczenie } \\
\text { zdolności biorących udział } \\
\text { w procesie kreatywności: } \\
\text { - abstrahowania } \\
\text { - dokonywania skojarzeń } \\
\text { - rozumowania } \\
\text { dedukcyjnego } \\
\text { i indukcyjnego przez } \\
\text { analogię, } \\
\text { - metaforyzowania oraz } \\
\text { transformowania } \\
\text { - scharakteryzowanie } \\
\text { modelu kreatywnego } \\
\text { myślenia oraz warunków } \\
\text { niezbędnych do } \\
\text { zainicjowania kreatywności } \\
\text { - kreatywne podejście do } \\
\text { problemu - przejście przez } \\
\text { kolejne etapy rozwiązywania } \\
\text { problemu przy poznaniu } \\
\text { i zastosowaniu takich } \\
\text { technik, jak: diagram } \\
\text { Ishikawy, pytania Osborne'a, } \\
\text { burza mózgów, „635” „dwa } \\
\text { wyrazy” } \\
\text { - jak wprowadzać zmiany } \\
\text { w klasie - sposoby radzenia } \\
\text { sobie z oporem wobec zmian }\end{array}$ & $\begin{array}{l}\text { Kreatywność - definicje pojęcia, } \\
\text { zasady twórczego i kreatywnego } \\
\text { myślenia } \\
\text { Jednostka twórcza - jakimi } \\
\text { cechami się charakteryzuje? } \\
\text { Proces twórczy: struktura, } \\
\text { strategie, przeszkody } \\
\text { Myślenie + zdolności twórcze = } \\
\text { postawa twórcza } \\
\text { Opis warunków niezbędnych do } \\
\text { zainicjowania kreatywności } \\
\text { Rozwój zdolności ułatwiających } \\
\text { kreatywne myślenie: } \\
\text { dokonywanie skojarzeń, } \\
\text { rozumowanie dedukcyjne } \\
\text { i indukcyjne, mataforyzowanie, } \\
\text { abstrahowanie } \\
\text { Jak rozwiązywać problemy } \\
\text { kreatywnie? } \\
\text { Autocharakterystyka - jakim } \\
\text { nauczycielem jestem? }\end{array}$ & $10 \mathrm{~h}$ \\
\hline
\end{tabular}




\begin{tabular}{|c|c|c|c|}
\hline Forma & Cele & Program & $\begin{array}{l}\text { Czas } \\
\text { trwania }\end{array}$ \\
\hline $\begin{array}{l}\text { Zajęcia } \\
\text { teoretyczne, } \\
\text { trening } \\
\text { twórczości }\end{array}$ & $\begin{array}{l}\text { - trening twórczości } \\
\text { - stanowi integralne } \\
\text { uzupełnienie modułu } \\
\text { teoretycznego } \\
\text { i służy aktywizacji } \\
\text { postawy twórczej oraz } \\
\text { wykorzystaniu wiedzy } \\
\text { zdobytej po realizacji części } \\
\text { teoretycznej }\end{array}$ & $\begin{array}{l}\text { Jak modyfikować program? } \\
\text { Jak wprowadzać innowacje? } \\
\text { - praktyczne wskazówki dla } \\
\text { wychowawców } \\
\text { Przedstawienie wybranych } \\
\text { metod i pomysłów na organizację } \\
\text { kreatywnego procesu kształcenia } \\
\text { w codziennej pracy } \\
\text { Trening twórczości w edukacji - } \\
\text { praktyka }\end{array}$ & $10 \mathrm{~h}$ \\
\hline \multicolumn{4}{|c|}{ Kreatywny nauczyciel - kreatywny uczeń } \\
\hline Warsztat & $\begin{array}{l}\text { Aktywowanie twórczego } \\
\text { potencjału przez: } \\
\text { - tworzenie czegoś nowego, } \\
\text { oryginalnego } \\
\text { - szukanie nowych } \\
\text { rozwiązań, patrzenie } \\
\text { z różnych perspektyw, } \\
\text { łączenie w ciekawy sposób } \\
\text { rzeczy i idei } \\
\text { - wychodzenie poza stare } \\
\text { schematy myślenia } \\
\text { - budzenie kreatywności } \\
\text { - pomoc w rozwinięciu } \\
\text { skrzydeł } \\
\text { - odkrywanie powołania } \\
\text { - wspieranie } \\
\text { w rozwiązywaniu } \\
\text { problemów } \\
\text { - znajdowanie inspiracji } \\
\text { dla realizacji codziennych } \\
\text { celów }\end{array}$ & $\begin{array}{l}\text { Doświadczenia kreatywności (na } \\
\text { własnej skórze) } \\
\text { Praca w podgrupach } \\
\text { Konkretne zadania wzbudzające } \\
\text { kreatywność } \\
\text { Testowanie na sobie procesu do } \\
\text { niestandardowego rozwiązywania } \\
\text { problemów }\end{array}$ & $3 \mathrm{~h}$ \\
\hline \multicolumn{4}{|c|}{ Lekcje bez nudy. Kreatywny nauczyciel - kreatywny uczeń } \\
\hline $\begin{array}{l}\text { Praktyczny } \\
\text { warsztat } \\
\text { szkoleniowy }\end{array}$ & $\begin{array}{l}\text { Zapoznanie z: } \\
\text { - metodami i technikami } \\
\text { stosowanymi } \\
\text { w procesie kształtowania } \\
\text { indywidualności twórczej, } \\
\text { w tym cech } \\
\text { osobowościowych, które } \\
\text { rzutują na przebieg } \\
\text { samoaktualizacji }\end{array}$ & $\begin{array}{l}\text { Ćwiczenia „startery”: } \\
\text { interpersonalne, tworzące atmosferę } \\
\text { twórczą, odreagowujące napięcie } \\
\text { psychofizyczne, przełamujące } \\
\text { bariery emocjonalne i motywacyjne, } \\
\text { tworzące klimat grupy; myślenie } \\
\text { dywergencyjne }\end{array}$ & $16 \mathrm{~h}$ \\
\hline
\end{tabular}




\begin{tabular}{|c|c|c|c|}
\hline Forma & Cele & Program & $\begin{array}{l}\text { Czas } \\
\text { trwania }\end{array}$ \\
\hline $\begin{array}{l}\text { Praktyczny } \\
\text { warsztat } \\
\text { szkoleniowy }\end{array}$ & $\begin{array}{l}\text { - metodami i technikami } \\
\text { stosowanymi w pobudzaniu } \\
\text { kreatywności grupy } \\
\text { - metodami i technikami } \\
\text { stymulującymi twórcze } \\
\text { myślenie i działanie } \\
\text { - metodami i technikami } \\
\text { twórczego pokonywania } \\
\text { problemów życiowych, } \\
\text { poznawczych i decyzyjnych } \\
\text { - metodami i technikami } \\
\text { wspierającymi harmonijny } \\
\text { rozwój wszystkich sfer } \\
\text { jednostki i jej postawy } \\
\text { twórczej }\end{array}$ & $\begin{array}{l}\text { Ćwiczenia myślenia pytanego, } \\
\text { pobudzające zdolności odkrywania, } \\
\text { formułowania i redefiniowania } \\
\text { problemów oraz ciekawość } \\
\text { poznawczą } \\
\text { Ćwiczenia myślenia } \\
\text { kombinacyjnego, asocjacyjne, } \\
\text { pobudzające zdolności łączenia } \\
\text { odległych skojarzeń i syntetyzowania } \\
\text { pomysłów } \\
\text { Ćwiczenia myślenia } \\
\text { transformacyjnego, rozwijające } \\
\text { zdolności przekształcania idei } \\
\text { i rzeczy w poszukiwaniu nowych } \\
\text { i oryginalnych rozwiązań } \\
\text { Twórcze rozwiązywanie problemów, } \\
\text { integrujące różne zdolności } \\
\text { i umiejęności w celu usprawnienia } \\
\text { procesu grupowego nad } \\
\text { generowaniem nowych pomysłów } \\
\text { Metodyka treningu kreatywności } \\
\text { - realizacja własnych projektów } \\
\text { działań }\end{array}$ & $16 \mathrm{~h}$ \\
\hline \multicolumn{4}{|c|}{ Trening twórczego rozwiązywania problemów } \\
\hline Warsztat & $\begin{array}{l}\text { Zapoznanie się z wybranymi } \\
\text { technikami twórczego } \\
\text { rozwiązywania problemów } \\
\text { (TRoP) i zdobycie } \\
\text { umiejętności stosowania } \\
\text { technik w rozwiązywaniu } \\
\text { rzeczywistych problemów } \\
\text { Rozwój umiejętności } \\
\text { twórczego myślenia, } \\
\text { efektywności w radzeniu } \\
\text { sobie z różnego rodzaju } \\
\text { sytuacjami problemowymi }\end{array}$ & $\begin{array}{l}\text { Proces twórczego myślenia i jego } \\
\text { składniki } \\
\text { Etapy twórczego rozwiązywania } \\
\text { problemów: jak stymulować } \\
\text { kreatywność na każdym etapie? } \\
\text { Przełomy kreatywności - sposoby } \\
\text { szybkiej zmiany kierunku myślenia } \\
\text { Techniki twórczego myślenia do } \\
\text { stosowania w pracy indywidualnej } \\
\text { i grupowej } \\
\text { Zasady pracy twórczej w grupie } \\
\text { - na co warto zwracać uwagę } \\
\text { z perspektywy uczestnika } \\
\text { i moderatora? }\end{array}$ & $8-10 \mathrm{~h}$ \\
\hline
\end{tabular}

Źródło: (Kreatywny nauczyciel; Lekcje bez nudy...; Trening twórczego rozwiązywania problemów...). 


\section{Podsumowanie badań}

W tab. 1 znajdują się przykładowe kursy i szkolenia dotyczące kreatywności. Ich adresatem są nauczyciele różnych etapów edukacyjnych lub całe rady pedagogiczne. W zasadzie wszystkie szkolenia tego typu koncentrują się na podobnych zagadnieniach i mają zbliżone cele, dlatego przedstawienie kilku zupełnie wystarczy, aby zyskać ogólne pojęcie na ten temat. Trzeba mieć świadomość, że sieć pełna jest takich ofert, więc nie ma problemów ze znalezieniem czegoś dla siebie. Należy tylko zadbać o to, by był to kurs prowadzony przez specjalistów z danej dziedziny. Niemal wszystkie tego rodzaju szkolenia mają formę warsztatów i zajęć praktycznych. Jest to ich niewątpliwa zaleta, ponieważ tylko samodzielne „przepracowanie” treści może dać jakiekolwiek efekty. Z pewnością jednak udział w takim kursie nie sprawi, że nauczyciel stanie się z dnia na dzień przykładem kreatora $i$ twórcy. Jest to bowiem proces długotrwały i wymagający ogromnej pracowitości i konsekwencji. Sam kurs wskazuje jedynie kierunek, w którym należy się poruszać, na co zwracać uwagę i jakimi metodami pracować. Nie zmienia to faktu, że warto uczestniczyć w takich warsztatach.

\section{ZAKOŃCZENIE}

Obecna rzeczywistość formułuje nowe oczekiwania pod adresem szkoły i nauczyciela. Priorytetem jest przygotowanie nowego pokolenia do funkcjonowania w świecie, który wymaga umiejętności samodzielności, twórczego i kreatywnego myślenia i działania, skutecznej komunikacji, korzystania z różnorodnych źródeł informacji, a zwłaszcza wykorzystywania zdobytej wiedzy w praktyce. Młody człowiek musi dzisiaj prezentować wysoki poziom kompetencji, pozwalający na wartościowe życie z perspektywy jednostki i społeczeństwa (Śliwierski 1988, s. 7). W związku z tym przed nauczycielami stawiane są wciąż coraz to szersze wymagania. Nie wystarczy dziś posiadać ogromnej wiedzy, tak jak to było dawniej. Nauczyciel nie jest już skarbnicą wiadomości, a szkoła tylko miejscem, w którym przekazuje się fakty i dane. Każdy, nawet najmłodszy, uczeń ma obecnie nieograniczony dostęp do informacji dzięki Internetowi i najnowocześniejszym urządzeniom technicznym. Inną kwestią jest umiejętność oceny, które z tych informacji są ważne i przydatne, a które to po prostu zwykłe „śmieci”. Nie zmienia to faktu, że to nie nauczyciel stanowi dla ucznia źródło wiedzy... Może być on jednak osobą, która nauczy go, jak z tej wiedzy korzystać w sposób twórczy, jak wykorzystać ją do rozwoju własnej osobowości, dodatkowo pokaże, jak kreować własną osobę w świecie, który oczekuje, że każdy będzie kimś wyjątkowym i niepowtarzalnym. 
Współczesny nauczyciel musi sprostać wielu nowym zadaniom dydaktycznym, wychowawczym, opiekuńczym i organizacyjnym. Przede wszystkim powinien mobilizować do poszukiwania odpowiedzi na pytania, które pojawią się w życiu uczniów. Najważniejszą wartością w jego pracy musi być dobro ucznia, odpowiedzialność za jego wszechstronny rozwój i przygotowanie go do pełnienia ról w życiu. Aby mógł zrealizować te cele, musi posiadać inne kompetencje niż dotychczas. Współczesna rzeczywistość edukacyjna potrzebuje nauczycieli otwartych i twórczych, pełniących rolę przewodników i thumaczy (Czaja 2001, s. 200-201). Kompetencje w tym zakresie nauczyciel zdobywa nie tylko podczas studiów, ale również w okresie swojej pracy, korzystając z bogatej oferty kursów, warsztatów i szkoleń.

\section{BIBLIOGRAFIA}

Borawska I. (1988), Dlaczego nauczyciel musi być twórczy?, „Edukacja i Dialog”, nr 8.

Cudowska A. (2004), Poczucie bezpieczeństwa personalnego w narracji kreatywności, [w:] D. Kowalski, M. Kwiatkowski, A. Zduniak (red.), Edukacja dla bezpieczeństwa. Wybrane perspektywy, Lublin-Poznań: Wydawnictwo O'chikara.

Czaja E. (2001), Zmieniająca się rola nauczyciela w szkole edukacji jutra, [w:] K. Denek, T.M. Zimny (red.), Edukacja jutra. VII Tatrzańskie Seminarium Naukowe, Częstochowa: Wydawnictwo Menos.

Drabik-Podgórna V. (2005), Innowacja edukacyjna w poradnictwie zawodowym, Kraków: Oficyna Wydawnicza Impuls.

Dudel B. (2014), Innowacje w teorii i praktyce edukacyjnej (na przykładzie województwa podlaskiego), Białystok: Fundacja Centrum Transferu Wiedzy i Innowacji Społeczno-Pedagogicznych.

Dymara B. (2003), Autorytet nauczyciela a przestrzenie wspótbycia z uczniami, [w:] K. Denek, K. Koszczyc, M. Lewandowski (red.), Edukacja jutra. IX Tatrzańskie Seminarium Naukowe, Wrocław: Wydawnictwo Wrocławskiego Towarzystwa Naukowego.

Dyrda B. (2004), Rozwijanie twórczości i inteligencji emocjonalnej dzieci i młodzieży. Poradnik dla wychowawców i nauczycieli, Kraków: Oficyna Wydawnicza Impuls.

Gaza T. (1998), Pedagogika twórczości w pracy nauczycielskiej, Kielce: WSP im. J. Kochanowskiego. Hurlock E. (1985), Rozwój dziecka, Warszawa: WSiP.

Informacje o trybie i warunkach uzyskania pozytywnej opinii na prowadzenie innowacji i eksperymentów pedagogicznych w szkołach i placówkach województwa świętokrzyskiego, 3 kwietnia 2011 r., http://kuratorium.kielce.pl/file_download/2010/Informacje+o+trybie+i+warunkac $\mathrm{h}+$ wdra $\% \mathrm{C} 5 \% \mathrm{BCania}+$ innowacji + pedagogicznych $+\mathrm{i}+$ eksperyment $\% \mathrm{C} 3 \% \mathrm{~B} 3 \mathrm{w}+1$.pdf (dostęp: 10.10.2017).

Jezierska E. (2012), Twórczy nauczyciel, twórczy uczeń, [w:] P. Siedlecka (red.), Uczyć łatwiej, Warszawa: PWN.

Karwat T. (1987), Podstawy innowatyki w oświacie, Kalisz: CDN.

Karwowski M. (2008), Spory wokót pojęcia kreatywności w pedagogice twórczości, „Ruch Pedagogiczny", nr 5/6.

Kotarba-Kańczugowska M. (2009), Innowacje pedagogiczne w międzynarodowych raportach edukacyjnych, Warszawa: Wydawnictwo Akademickie Żak. 
Kowalczuk-Walędziak M. (2012), Poczucie sprawstwa spolecznego pedagoga. Studium teoretyczno-empiryczne, Kraków: Oficyna Wydawnicza Impuls.

Kreatywny nauczyciel, http://cognitus.pl/szkolenia-2/dla-rad-pedagogicznych/kreatywny-nauczyciel (dostęp: 10.10.2017).

Lekcje bez nudy. Kreatywny nauczyciel - kreatywny uczeń, http://eko-tur.pl/szkolenia/3,Szkolenia rad_pedagogicznych-dla_szkol;3467,Lekcje_bez_nudy._Kreatywny_nauczyciel_-_kreatywny_uczen (dostęp: 10.10.2017).

Morbitzer J. (2003), Nauczyciel w społeczeństwie informacyjnym, [w:] K. Denek, K. Koszczyc, M. Lewandowski (red.), Edukacja jutra. IX Tatrzańskie Seminarium Naukowe, Wrocław: Wydawnictwo Wrocławskiego Towarzystwa Naukowego.

Nęcka E. (1995), Proces twórczy i jego ograniczenia, Kraków: Oficyna Wydawnicza Impuls.

Nęcka E. (2001), Psychologia twórczości, Gdańsk: Gdańskie Wydawnictwo Psychologiczne.

Nöllke M. (2007), Techniki kreatywności. Jak wpadać na lepsze pomysty, Kraków: Flashbook.

Okoń W. (1979), Szkoła wspótczesna: przemiany i tendencje rozwojowe, Warszawa: Książka i Wiedza.

Okoń W. (2001), Nowy słownik pedagogiczny, Warszawa: Wydawnictwo Akademickie Żak.

Piątek T., Wańczyk B., Pokorska E. (2007), Samoświadomość nauczyciela w kontekście podejmowanych przez niego działań pedagogicznych, [w:] E.I. Laska (red.), Nauczyciel wobec wczesnej edukacji dzieci, Rzeszów: Wydawnictwo Uniwersytetu Rzeszowskiego.

Pietrasiński Z. (1969), Myślenie twórcze, Warszawa: PZWS.

Schulz R. (1996), Studia z innowatyki pedagogicznej, Toruń: Uniwersytet Mikołaja Kopernika.

Strzałecki A. (1969), Wybrane zagadnienia z psychologii twórczości, Warszawa: PWN.

Such R. (2007), Innowacje pedagogiczne, Tarnów 2007, www.sce.pl/upload/File/Renata\%20 Such\%20-\%20Innowacje\%20pedagogiczne.pdf (dostęp: 10.10.2017).

Szmidt K. (2008), Trening kreatywności. Podręcznik dla pedagogów, psychologów i trenerów grupowych, Gliwice: Wydawnictwo Helion.

Śliwierski B. (1988), Jak zmieniać szkołę. Studia z polityki oświatowej i pedagogiki porównawczej, Kraków: Oficyna Wydawnicza Impuls.

Tatarkiewicz W. (1976), Dzieje sześciu pojęć, Warszawa: PWN.

Trening twórczego rozwiazywania problemów. NOWOŚĆ!, www.mnodn.kangur.edu.pl/kurs. php?kk=3832 (dostęp: 10.10.2017).

Wojtczuk-Turek A. (2009), Znaczenie wiedzy jako istotnego komponentu kompetencji twórczych $w$ generowaniu innowacji, [w:] S. Popek (red.), Psychologia twórczości. Nowe horyzonty, Lublin: Wydawnictwo UMCS.

\section{SUMMARY}

The modern teacher must meet many new didactic, educational, care and organizational tasks. To be able to accomplish new goals, he/she must have other competencies than before. Modern educational reality requires open and creative teachers, who act as guides and translators. Competence in this field is not only gained by the teacher during his/her studies but also during his/her work, using a wide range of courses, workshops and training. The ideal teacher should have not only competence, psychological-pedagogical, communication, negotiation and auto-education, but also creative and innovative personality. Due to the need to educate the creativity and creative attitude of teachers on the market, there is a wide range of courses, training and postgraduate courses offering courses that deal with this area.

Keywords: creativity; innovation; teacher 